\title{
日本薬局方と生物薬品
}

\author{
石井明子
}

\section{Role of the Japanese Pharmacopoeia in the Quality Assurance of Biologics}

\author{
Akiko Ishii-Watabe \\ Division of Biological Chemistry and Biologicals, National Institute of Health Sciences; \\ 3-25-26 Tonomachi, Kawasaki-ku, Kawasaki 210-9501, Japan.
}

(Received November 29, 2019)

\begin{abstract}
Biologics listed in the Japanese Pharmacopoeia (JP) include drugs in which the active pharmaceutical ingredient is a peptide, protein, or polysaccharide. Biologics were previously manufactured by purification from biological sources, however, most recently developed products are manufactured using biotechnology such as genetic recombination and cell culture technologies. The JP provides useful information to ensure the quality of such products in the form of monographs, general test, and general information. A recent topic related to biologics is the adoption of general test $\langle 6.17\rangle$ “Insoluble Particulate Matter Test for Protein Injections". Test $\langle 6.17\rangle$ enables the determination of insoluble particulate matter using the light obscuration method with smaller sample volumes and indicates points to consider in handling protein samples. In addition, the draft general information "Basic Concept of Quality Assurance of Biotechnology Products (Biopharmaceuticals)" has been released for public consultation and will be listed in the 18th edition of the JP. In this review, the contents of JP monographs, general chapters, and general information on biologics are introduced, and future perspectives on the role of the JP for ensuring the quality of biologics are discussed.
\end{abstract}

Key words___ Japanese Pharmacopoeia; biologics; quality assurance

\section{1. はじめに}

日本薬局方（以下，日局）には，ペプチド，タン パク質, 多糖類を有効成分とする生物薬品各条が収 載されている。 また, ワクチン, トキソイド等, 生 物学的製剂基準に各条が収載されている製品のいく つかについても日局に各条が収載されており，これ らについては，本質と性状のほか, 生物学的製剂基 準の各条に適合することが記されている。古典的な 生物薬品は, 生体試料から抽出した成分を医薬品と するものであったが，近年では，ペプチドは化学合 成あるいは遺伝子組換えに，タンパク質は遺伝子組 換えにより製造されるものが主流となっている。へ パリンに代表される多糖類は，化学合成には移行し ておらず，現在でも生体試料由来のものが用いられ ている.

国立医薬品食品衛生研究所生物薬品部（干210-9501 川 崎市川崎区殿町 3-25-26)

e-mail:watabe@nihs.go.jp

本総説は, 日本薬学会第 139 年会シンポジウムS22 で

発表した内容を中心に記述したものである.
2000 年以降, 承認品目が顕著に増加している遺 伝子組換え技術・細胞培養技術を用いて製造される バイオテクノロジー応用医薬品（バイオ医薬品）を 含め, 生物薬品には医療上重要な製品が多い。日局 では, 各条, 一般試験法, 参考情報の新規収載と改 正を通じて，これら生物薬品の品質確保に有用な情 報が提供されている。本稿では，日局に収載されて いる生物薬品各条，及び，生物薬品に関連する一般 試験法と参考情報を紹介し, 生物薬品, 特にバイオ 医薬品の品質確保における日局の役割について考察 する.

\section{2. 生体試料由来生物薬品に関する日局各条}

日局に収載されている生物薬品の中で，生体試料 に由来するものを Table 1 に示した。 生体試料由来 ペプチドであるプロタミン硫酸塩は, サケ科 （Salmonidae）魚類の成熟した精巣から得たプロタ ミンの硫酸塩で，へパリンに結合する性質を有す る. 日局には, オキシトシン, バソプレシン, エル カトニン, リュープロレリン酢酸塩等, 様々なペプ チドの各条が収載されているが，いずれも化学合成 
Table 1. JP Monographs of Biologics Derived from Natural Sources

\begin{tabular}{l|l}
\hline \hline \multicolumn{1}{c|}{ Category } & \multicolumn{1}{c}{ Monograph } \\
\hline Peptide & Protamine Sulfate \\
\hline \multirow{5}{*}{ Protein } & Ulinastatin \\
& Urokinase \\
& Kallidinogenase \\
& Saccharated Pepsin \\
& Thrombin \\
& Human Menopausal Gonadotrophin \\
& Human Chorionic Gonadotrophin \\
\hline \multirow{3}{*}{ Polysaccharide } & Heparin Sodium \\
& Heparin Calcium \\
& Parnaparin Sodium \\
& Purified Sodium Hyaluronate \\
\hline
\end{tabular}

により製造されるものである，オキシトシンやバソ プレシンのように，従来，生体試料由来のものが用 いられていたペプチドの場合は，基原の中に，化学 合成により製造されることが記載されている.

生体試料に由来するタンパク質としては, ウリナ スタチン，ウロキナーゼ，カリジノゲナーゼ，含糖 ペプシン, トロンビン, ヒト下垂体性性腺刺激ホル モン，ヒト絨毛性性腺刺激ホルモンの各条が収載さ れている，いずれも，基原の中に，由来となる試料 が示されており，例えば，ヒト絨毛性性腺刺激ホル モンは，本品は健康な妊婦の尿からウイルスを除去 又は不活化する工程を経て得た性腺刺激ホルモンを 乾燥したもの，と記載されている.

多糖類としては，ヘパリンナトリウム，ヘパリン カルシウム，及び，精製ヒアルロン酸ナトリウムの 各条が収載されている。ヘパリンナトリウムは，健 康な食用ブタの腸粘膜から得た D-グルコサミン及 びウロン酸（L-イズロン酸又は D-グルクロン酸） の二糖単位からなる硫酸化グリコサミノグリカンの ナトリウム塩であり，血液凝固の防止等に用いられ る.

生体試料に由来する生物薬品については，同一の 一般的名称の原薬を使用した複数の製剤が承認され ているものがあり，化学薬品と同様，製品横断的 に，日局各条の試験が規格及び試験方法として用い られている。

\section{3. バイオ医薬品の一般的名称と日局各条}

第十七日本薬局方第二追補 [Japanese Phar-
macopoeia（JP）17-2] までに収載されているバイ 才医薬品各条を Table 2 に示した。遺伝子組換えに より製造されるバイオ医薬品は，一般的名称に（遺 伝子組換え）を含んでおり，Table 2 に示す Insulin Human（Genetical Recombination）の日本語での 表記は，インスリン ヒト(遺伝子組換え)である. 有効成分が糖タンパク質であり，生産細胞の違いに よる糖鎖構造の違いを示す必要がある場合は，二語 式の命名となる、Table 2 の中では, エポエチン アルファ（遺伝子組換え）及びエポエチン ベータ （遺伝子組換え）がその例である。エポエチン ア ルファ（遺伝子組換え）とエポエチン ベータ（遺 伝子組換え）は，ぞちらも $\mathrm{CHO}$ 細胞で生産される が，独立して樹立されたセルバンクを用いて，それ ぞれの方法で製造されるため，糖鎖構造は異なる。 独立して開発された製品であり，品質管理戦略や規 格及び試験方法が異なり，各条もそれぞれに作成さ れている.

バイオ医薬品の有効成分には不均一性があり, 先 行品とバイオ後続品(バイオシミラー)においても, 有効成分は同一ではない。そのため，バイオシミ ラーに関しては，エポエチン カッパ（遺伝子組換 え）［エポエチンアルファ後続 1］のような一般 的名称となり，先行品とバイオシミラーは，それぞ れ独自の一般的名称を持つことになる。したがつ て，例えば，エポエチン カッパ（遺伝子組換え） [エポエチン アルファ後続 1] は, エポエチン アルファ（遺伝子組換え）のバイオシミラーである が，エポエチン アルファ（遺伝子組換え）各条の 規格及び試験方法は適用されない。この点は，有効 成分が唯一に確定している低分子医薬品において, 1 つの各条が, 先発品及び複数の後発品に共通する 規格及び試験方法として利用されていることと大き く異なっている.

ただし，Table 2 に示すインスリン ヒト（遺伝 子組換え）については，1980-1990 年代に，複数の 企業が独立して開発し，それぞれ新薬として承認さ れた製品があり，いずれも，一般的名称がインスリ ン ヒト（遺伝子組換え）であることから，日局各 条の試験が共通して原薬の規格及び試験方法として 用いられている。また，インスリン ヒト（遺伝子 組換え）注射液，イソフェンインスリン ヒト（遺 伝子組換え）水性懸濁注射剂，及び二相性イソフェ 
Table 2. JP Monographs of Biologics (Therapeutic Proteins)

\begin{tabular}{|c|c|c|}
\hline Category & Monograph & $\begin{array}{l}\text { First adopted } \\
\text { issue }\end{array}$ \\
\hline Insulins & $\begin{array}{l}\text { Insulin Human (Genetical Recombination) } \\
\text { Insulin Human (Genetical Recombination) Injection } \\
\text { Insulin Glargin (Genetical Recombination) } \\
\text { Insulin Glargin (Genetical Recombination) Injection } \\
\text { Insulin Aspart (Genetical Recombination) } \\
\text { Isophane Insulin Human (Genetical Recombination) Injectable Aqueous Suspension } \\
\text { Biphasic Isophane Insulin Human (Genetical Recombination) Injectable Aqueous Suspension }\end{array}$ & $\begin{array}{l}\text { JP14 } \\
\text { JP16-2 } \\
\text { JP16-2 } \\
\text { JP16-2 } \\
\text { JP17-1 } \\
\text { JP17-1 } \\
\text { JP17-1 }\end{array}$ \\
\hline Interleukin-2 & $\begin{array}{l}\text { Celmoleukin (Genetical Recombination) } \\
\text { Teceleukin (Genetical Recombination) } \\
\text { Teceleukin for Injection (Genetical Recombination) }\end{array}$ & $\begin{array}{l}\text { JP15 } \\
\text { JP15 } \\
\text { JP15 }\end{array}$ \\
\hline $\begin{array}{l}\text { Granulocyte- } \\
\text { Colony } \\
\text { Stimulating } \\
\text { Factors }\end{array}$ & $\begin{array}{l}\text { Filgrastim (Genetical Recombination) } \\
\text { Filgrastim (Genetical Recombination) Injection } \\
\text { Lenograstim (Genetical Recombination) } \\
\text { Nartograstim (Genetical Recombination) } \\
\text { Nartograstim for Injection (Genetical Recombination) }\end{array}$ & $\begin{array}{l}\text { JP16-1 } \\
\text { JP16-1 } \\
\text { JP16-1 } \\
\text { JP16-1 } \\
\text { JP16-1 }\end{array}$ \\
\hline Erythyropoietins & $\begin{array}{l}\text { Epoetin Alfa (Genetical Recombination) } \\
\text { Epoetin Beta (Genetical Recombination) }\end{array}$ & $\begin{array}{l}\text { JP16-1 } \\
\text { JP16-1 }\end{array}$ \\
\hline Interferons & $\begin{array}{l}\text { Interferon Alfa (NAMALWA) } \\
\text { Interferon Alfa (NAMALWA) Injection }\end{array}$ & $\begin{array}{l}\text { JP17 } \\
\text { JP17 }\end{array}$ \\
\hline
\end{tabular}

ンインスリン ヒト（遺伝子組換え）水性懸濁注射 剤についても，複数の製剤が承認されており，日局 製剤各条の試験が，共通して製剤の規格及び試験方 法として用いられている. Table 2 に挙げた品目の うち，インスリン ヒト及びその製剤以外について は，いずれも，製造販売承認を持つ 1 つの企業が販 売している原薬あるいは製凨に関する各条である.

\section{4. 生物薬品部関連の一般試験法}

生物薬品に関連の深い一般試験法を Table 3 に示 す。このうち，直近の JP17-2 で収載されたのは， 一般試験法〈6.17〉 タンパク質医薬品注射剤の不溶 性微粒子試験法，である。これまで注射剂の不溶性 微粒子試験には，一般試験法〈6.07〉 注射剂の不溶 性微粒子試験法が用いられてきており, $10 \mu \mathrm{m}$ 以上 及び $25 \mu \mathrm{m}$ 以上の大きさの微粒子について，上限 值が設定されている。タンパク質医薬品注射剂に は，外来性の物質，製造工程に由来する物質及び処 方成分や容器からの溶出物に加えて有効成分それ自 身が凝集してできた微粒子が含まれる可能性があ り，タンパク質凝集体と免疫原性の関連も指摘され ていることから，不溶性微粒子の評価と管理は重要 である。しかし，〈6.07〉はタンパク質医薬品注射 剂が今ほど多くない時代に策定されたものであり,
Table 3. JP General Tests Related to Biologics

\begin{tabular}{l|c}
\hline \hline \multicolumn{1}{c|}{ Chapter } & $\begin{array}{c}\text { Harmonisation } \\
\text { in PDG }\end{array}$ \\
\hline 2.01 Liquid Chromatography & \\
\hline 2.04 Amino Acid Analysis of Proteins & - \\
\hline 2.64 Glycosylation Analysis of Glycoprotein & - \\
\hline 4.01 Bacterial Endotoxins Test & $\bigcirc$ \\
\hline 4.06 Sterility Test & $\bigcirc$ \\
\hline $\begin{array}{l}\text { 6.05 Test for Extractable Volume of Paren- } \\
\text { teral Preparations }\end{array}$ & $\bigcirc$ \\
\hline $\begin{array}{l}\text { 6.06 Foreign Insoluble Matter Test for Injec- } \\
\text { tions }\end{array}$ & - \\
\hline $\begin{array}{l}\text { 6.07 Insoluble Particulate Matter Test for } \\
\text { Injections }\end{array}$ & $\bigcirc$ \\
\hline $\begin{array}{l}\text { 6.17 Insoluble Particulate Matter Test for } \\
\text { Protein Injections }\end{array}$ & \\
\hline
\end{tabular}

タンパク質医薬品注射剤を第 1 法である光遮蔽粒子 計数法により試験する際には，1）タンパク質医薬 品注射剂の多くは容量が少なく，試験を実施するた めには多数の容器内の溶液を混合して試験を行う必 要がある，2）タンパク質溶液は試験中の不適切な 取扱いにより凝集体や気泡を形成する可能性があ る，といつた課題があった. 
〈6.17〉 タンパク質医薬品注射剂の不溶性微粒子 試験法は，これらの点を踏まえ，一般試験法におい て，タンパク質医薬品注射剂の取扱いの留意事項を 記載するとともに，近年の製品開発動向や装置性能 の向上を踏まえ，試験液量の低容量化を図ったもの である. ${ }^{1)}\langle 6.07\rangle$ では， $25 \mathrm{~mL}$ 以上の試料溶液を用 意し， 1 測定の容量を $5 \mathrm{~mL}$ 以上とすることが求め られているが, $\langle 6.17\rangle$ では, $\langle 6.07\rangle$ の装置の項に 示されている要件を満たす装置であれば， 1 測定の 容量を $5 \mathrm{~mL}$ から $1 \mathrm{~mL}$ まで減らしてもよいとされ た。また，妥当性が確認できれば， 1 測定の容量を $0.2 \mathrm{~mL}$ まで減らすことも可能とされている，妥当 性を確認する方法としては，実試料や試料マトリッ クス等を用いて，設定した測定容量において $\langle 6.07\rangle$ で示された試料容量精度の基準を満たしているこ と，さらに，測定容量を 1-5 mL で測定した平均微 粒子数と，より低容量の測定容量で測定した平均微 粒子数が同等であることを確認すること等が考えら れる. タンパク質溶液の取扱いに関しては，〈6.07〉 では, 気泡の除去の方法として超音波処理が挙げら れているが，タンパク質溶液には適切ではないた め，〈6.17〉では，超音波処理は適切でないと記載 され，気泡の発生に注意すべきであることも述べら れている.

$\langle 6.17\rangle$ の収載に伴い，製剤総則 [3］製剂各条 3.1 注射剂の項において，（14）本剤及び添付された 溶解液などは，別に規定するもののほか，注射剤の 不溶性微粒子試験法〈6.07〉 又はタンパク質医薬品 注射剂の不溶性微粒子試験法〈6.17〉に適合する, との記載が追加され，不溶性微粒子試験法として, $\langle 6.07\rangle$ と〈6.17〉のいずれかを用いることが可能 となっている．なお，〈6.17〉では，第 1 法（光遮 蔽粒子計数法）の夕を取扱い，第 2 法（顕微鏡粒子 計数法）は取り扱っていない.

United States Pharmacopeia (USP) では, 〈787〉 Subvisible Particulate Matter in Protein Injections $と$ して， 1 測定の容量を $5-0.2 \mathrm{~mL}$ とする不溶性微粒 子試験が収載されており，今後は，三局での調和が 望まれる。

\section{5. 生物薬品関連の参考情報}

Table 4 に生物薬品に関連する参考情報を示す. このうち，直近の JP17-2 では，宿主細胞由来タン パク質試験法が収載された。宿主細胞由来タンパク
Table 4. JP General Informations Related to Biologics

\begin{tabular}{l|c}
\hline \hline \multicolumn{1}{c|}{ Chapter } & $\begin{array}{c}\text { Harmonisation } \\
\text { in PDG }\end{array}$ \\
\hline (G3) Amino Acid Analysis & $\bigcirc$ \\
\hline (G3) SDS-Polyacrylamide Gel Electrophoresis & $\bigcirc$ \\
\hline (G3) Capillary Electrophoresis & $\bigcirc$ \\
\hline (G3) Enzyme-linked Immunosorbent Assay & \\
(ELISA) & \\
\hline (G3) Host Cell Protein Assay & \\
\hline (G3) Total Protein Assay & \\
\hline (G3) Monosaccharide Analysis and Oligosac- & \\
charide Analysis/Oligosaccharide Profiling & \\
\hline (G3) Isoelectric Focusing & \\
\hline (G3) Surface Plasmon Resonance & \\
\hline (G3) Mass Spectrometry of Peptides and & \\
Proteins & \\
\hline (G3) Peptide Mapping & \\
\hline (G3) Basic Requirements for Viral Safety of & \\
Biotechnological/Biological Products listed & \\
in Japanese Pharmacopoeia & \\
\hline (G3) Mycoplasma Testing for Cell Substrates & \\
used for the Production of Biotechnological/ & \\
Biological Products & \\
\hline
\end{tabular}

質（host cell protein; HCP） は，医薬品製造に用い た宿主細胞に由来するタンパク質の総称である，組 換えタンパク質医薬品に残留した HCP は，それ自 身が抗原として免疫反応を引き起こす原因となる可 能性があり，また，抗薬物抗体を誘導するアジュバ ントとなることが懸念される。したがって，組換え タンパク質医薬品の有効性と安全性を確保するため に，製造工程の開発においては，HCP を安全性に 影響のないレベルまで減少させる製法を確立するこ とが必要である．また，工程内試験で HCP が恒常 的に除去できていることの検証，あるいは，原薬の 純度試験の設定により，HCP 残留量を適切に管理 しなければならない，本参考情報収載では，遺伝子 組換え技術を用いて製造されたタンパク質医薬品 （組換えタンパク質医薬品）を対象に，HCP に関す る試験における留意事項について述べられている.

日局全体の方針として，International Council for Harmonisation of Technical Requirements for Pharmaceuticals for Human Use (ICH) の品質ガイドラ インに記載されている基本的な品質保証の概念と日 局の関係を明確化することを目的に, 各種 ICH ガ イドラインの参考情報への取り込みが進められてき 
Table 5. Basic Concept of the Quality Assurance of Biologics (Therapeutic Proteins)

Introduction

1. Quality evaluation and control of biopharmaceuticals

1.1. Quality evaluation

1.1.1. Characterization

1.1.2. Identification of CQA

1.2. Development of quality control strategy

1.2.1. Raw materials control

1.2.2. Manufacturing process control

1.2.3. Evaluation and control of contaminants

1.2.4. Specifications

1.2.5. Stability testing

2. Comparability of biopharmaceuticals subject to changes in their manufacturing process

2.1. Considerations for the comparability exercise

2.2. Quality considerations

2.3. Manufacturing process considerations

た．参考情報「医薬品原薬及び製剤の品質確保の基 本的考え方」には，近年，医薬品の品質は，原料・ 資材の管理を含む製造工程における管理及び最終製 品の品質試験を相互補完的に行うことで確保される という考え方が主流となっていることが記載され， 参考情報「品質リスクマネジメントの基本的考え方」 には，品質リスクマネジメントは，原薬，製剤，生 物薬品（生物起源由来医薬品及びバイオテクノロ ジ一応用医薬品）を含むあらゆる医薬品の品質確保 に適用できるものであることが示されている。これ らの方針に沿った日局改正の一環として，ICH ガ イドラインをベースにバイオ医薬品の品質確保の考 え方をまとめた参考情報案「バイオテクノロジー応 用医薬品（バイオ医薬品）の品質確保の基本的考え 方」が作成され，JP18 での収載に向けて，2019年 6 月に意見募集が行われた. ${ }^{2}$

本参考情報の目次を Table 5 に示す．1.バイオ医 薬品の品質評価・管理，において，1.1. 品質評価 (特性解析, 重要品質特性の特定), 1.2. 品質管理戦 略の構築（原材料の管理，製造工程の管理，混入污 染物質の評価と管理，規格及び試験方法，安定性試 験）に関する基本的事項が述べられ，続いて，

2. 製造工程の変更にともなう同等性／同質性評 価，において，2.1. 同等性／同質性評価作業に関す る留意事項, 2.2. 品質に関する留意事項, 2.3. 製造 工程に関する留意事項，に関して述べられている. 本参考情報は，Fig. 1 に示すように， ICH 品質ガ

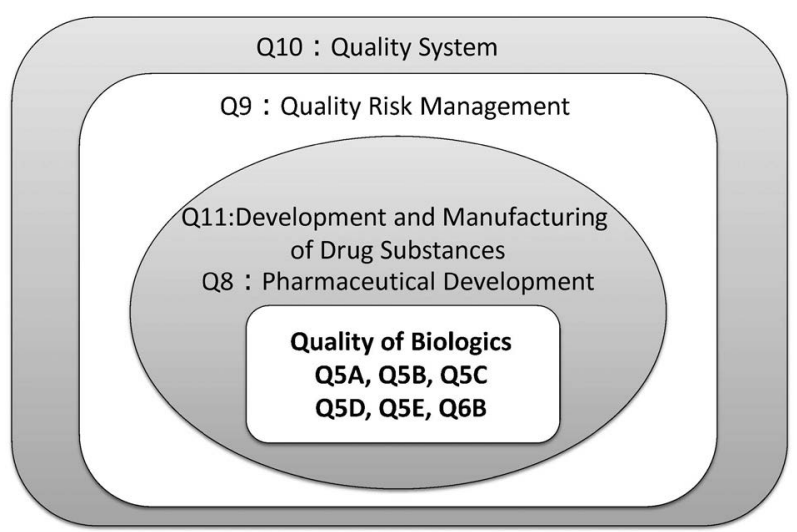

Fig. 1. ICH Guidelines Related to the Quality of Biologics

イドライン $\mathrm{Q}$ カルテット（Q8-Q11）に述べられて いる品質管理戦略構築に関する考え方をべースに,

ICH Q5 シリーズ，すなわち，Q5A（ウイルス安全 性), Q5B（遺伝子発現構成体）, Q5C (安定性),

Q5D（セルバンク）, Q5E（製法変更時の同等性/ 同質性確保）及び Q6B（規格及び試験方法）に示 される各論の基本的考え方を基に作成されたもので ある，本参考情報では，バイ才医薬品の品質確保に 関する各論が，品質リスクマネジメントの流れの中 でどのように活用されるかについて，簡潔にまとめ られていることから，日局への収載により，バイオ 医薬品の品質確保の基盤になる資料として，国内外 で活用されることが期待される.

\section{6. 日局生物薬品に関する展望}

バイオ医薬品の承認品目の増加に伴い，適応疾患 が広がり，医療上の重要性がますます高まってい る. 日局において，バイオ医薬品の各条収載を進め ることは，保健医療上重要な医薬品の全面的収載を 目標とする日局作成の基本方針にも合致している.

しかし，本稿の 3. で述べたように，バイオ医薬品 では，1つの各条が 1 つの製品のみの規格及び試験 方法を示すこととなり, 先発品と後発品に共通する 規格及び試験方法として各条が活用される化学薬品 とは，日局各条の位置づけが異なっている．このた め，日局のみならず，欧米においてもバイオ医薬品 各条の収載が進んでいない状況にあるが, 今後, 例 えば，製造要件の闌を活用した各条の記載方法や， 先行品と後続品に共通する重要品質特性と代表的な 管理戦略を示す複合的な各条の作成等，バイオ医薬 品の特徵に応じた各条の収載方法の検討が必要と考 えられる。 
各条収載の推進と並行して，日局の基本方針であ る最新の学問・技術の積極的導入による質的向上を 達成するため, 一般試験法や参考情報を拡充してい くことが特に重要と考えられる，バイオ医薬品はグ ローバルに開発される製品が多いことから，医薬品 のグローバル化に対応した国際化を一層推進するた めにも，一般試験法や参考情報の国際調和も重要で ある。一般試験法の国際調和は，医薬品開発の効率 化に特に有用と考えられることから，注射剤の不溶 性微粒子試験を含め, 議論の加速が望まれる.

謝辞本研究の一部は, AMED 医薬品等規制 調和・評価研究事業「薬局方各条改正を指向した医 薬品品質確保の為の研究」及び「日本薬局方の試験 法開発と規格設定による医薬品の品質確保に関する 研究」により行われました。 日局生物薬品関連の各
条や一般試験法・参考情報の原案検討においてお世 話になりました(独)医薬品医療機器総合機構審査マ ネジメント部医薬品基準課及び，日本薬局方原案検 討委員会生物薬品委員会の皆様に深謝いたします.

利益相反＼cjkstart開示すべき利益相反はない.

\section{REFERENCES}

1) Harazono A., Shibata H., Kiyoshi M., Muto T., Fukuda J., Torisu T., Saitoh S., Nishimura H., Uchiyama S., Ishii-Watabe A., Biologicals, 57, 46-49 (2019).

2) Proposed general information, "A basic concept of the quality assurance on biotechnological products (biopharmaceuticals).": 〈https: //www.pmda.go.jp/files/000229666.pdf , cited 28 September, 2019. 